\title{
Alternatives to in-feed antibiotics in pigs: Evaluation of probiotics, zinc or organic acids as protective agents for the intestinal mucosa. A comparison of in vitro and in vivo results
}

\author{
Marianna ROSELLI ${ }^{\mathrm{a}}$, Alberto FINAMORE ${ }^{\mathrm{a}}$, Maria Serena BRITTI ${ }^{\mathrm{a}}$, \\ Paolo Bosi $^{\mathrm{b}}$, Isabelle OsWALD ${ }^{\mathrm{c}}$, Elena MENGHERI ${ }^{\mathrm{a} *}$ \\ a Istituto Nazionale di Ricerca per gli Alimenti e la Nutrizione (INRAN), Via Ardeatina 566, \\ 00178 Roma, Italy \\ b DIPROVAL, University of Bologna, Italy \\ c INRA Pharmacologie-Toxicologie, Toulouse, France
}

(Received 10 May 2004; accepted 14 Mars 2005)

\begin{abstract}
Weaned pigs are susceptible to frequent infectious diseases. Antibiotics have been used over decades to reduce pathogen infections, but many microorganisms are becoming resistant to antibiotics. Thus, there is an urgent need to find alternatives to in-feed antibiotics. Up to now, various compounds have been used as alternatives, giving promising but sometimes contrasting results. In recent years, the in vitro models of cell culture have been proposed for the screening of various compounds and understanding their mechanisms of action. The intestine is a complex system with a continuous cross-talk among epithelial cells, the local immune system and microflora. Alternatives to in-feed antibiotics may interact with any of these constituents. This review presents data on the protective effects of probiotics, zinc salts and organic acids, used as alternatives to in-feed antibiotics, against pathogen induced damage and inflammatory processes in the intestinal cells and the underlying mechanisms, with an attempt to compare in vitro and in vivo results. All the alternatives tested resulted in effective protection against pathogens by a series of interactions with intestinal cells and pathogens, including the inhibition of adhesion and invasion of pathogens, interference in signalling pathways induced by pathogenic bacteria, maintenance of the epithelial cell cytoskeleton and junctional structure and modulation of the host immune response.
\end{abstract}

antibiotic alternative / intestinal cell culture / probiotic / zinc oxide / organic acid

Résumé - Alternatives aux antibiotiques additifs alimentaires chez le porc : évaluation des probiotiques, sels de zinc ou acides organiques comme agents protecteurs de la muqueuse intestinale. Comparaison des résultats in vitro avec les observations in vivo. Le porcelet est sensible aux infections gastro-intestinales au moment du sevrage. Les antibiotiques additifs alimentaires ont été utilisés pendant des décennies pour réduire ces infections, mais de nombreux

* Corresponding author: mengheri@inran.it 
microorganismes sont devenus résistants à ces substances. Aussi, est-il urgent de trouver des alternatives aux antibiotiques additifs alimentaires. Jusqu'à présent, diverses alternatives ont été envisagées, certaines donnant des résultats prometteurs, d'autres des résultats variables. Au cours des dernières années, les modèles in vitro de cultures cellulaires ont été proposés pour cribler ces substances et élucider leurs mécanismes d'action. L'intestin est un système complexe faisant intervenir des communications permanentes entre les cellules épithéliales, le système immunitaire local et la microflore. Les alternatives aux antibiotiques peuvent interagir avec n'importe lequel de ces composants. Le présent article fait la synthèse des effets protecteurs et des mécanismes d'action des probiotiques, des sels de zinc et des acides organiques, utilisés comme alternatives aux antibiotiques dans les processus inflammatoires et les altérations cellulaires épithéliales in vitro, induites par des agents pathogènes. Elle tente de comparer ces résultats avec les observations in vivo. Toutes les alternatives évaluées ont été efficaces contre les agents pathogènes, via des mécanismes d'interaction cellules épithéliales-agents pathogènes. Ces mécanismes incluaient l'inhibition de l'adhésion et de l'invasion cellulaire par ces pathogènes, la modulation des mécanismes de signalisation intracellulaire induits par les bactéries pathogènes, le maintien de la structure du cytosquelette et des jonctions serrées des cellules épithéliales, et enfin la modulation des réponses immunitaires de la cellule hôte.

alternative aux antibiotiques / cellule épithéliale en culture / probiotique / oxyde de zinc / acide organique

\section{INTRODUCTION}

The weaning period of pigs is frequently associated with infectious disease and diarrhoea. Enterotoxigenic Escherichia coli (ETEC) is the most common etiologic agent of enteric disease in piglets, accounting for the high mortality that occurs annually [27]. Antibiotics have been used over decades to reduce pathogen infection, but many bacteria are becoming resistant to antibiotics. Thus, there is an urgent need to find alternatives to in-feed antibiotics, especially after the full ban of antibiotic use from the European Community forecasted for early 2006. Up to now, various compounds have been used as in-feed antibiotic alternatives, such as organic acids, probiotics and zinc salts, that have given promising but sometimes contrasting results.

A major concern in the development of new strategies is the lack of knowledge of the mechanisms through which the substances that are alternatives to antibiotics can protect intestinal cells from the damage induced by pathogens. The intestine is a complex system in which three major components, the mucosal barrier, microflora and local immune system, provide defen- sive means through permanent contact and dialogue with each other. Alternatives to infeed antibiotics may interact with any of these constituents. Thus, the better knowledge of how the in-feed antibiotic alternatives work is important in order to understand their role in intestinal cell protection and to finally select those able to provide such protection in piglets.

In this review, recent data on the protective effects of some currently used alternatives to in-feed antibiotics, i.e. probiotics, zinc and organic acids, against infectious disease on the intestine are reported. A focus is given on the results obtained on in vitro cell culture models aimed at better defining the underlying mechanisms of alternative protection, such as the maintenance of barrier integrity, inhibition of pathogen adhesion and modulation of immune response, with an attempt of comparison with in vivo studies. We also report our recent studies conducted on two intestinal cell lines, the human Caco- 2 cells and the porcine IPEC-1 cells, that express in culture morphological and functional characteristics of some of the differentiated cytotypes of the intestinal mucosa. The Caco- 2 cell line, derived from a colon adenocarcinoma, 
undergoes a spontaneous process of differentiation leading to the formation of a monolayer of highly polarised cells, joined by tight junctions, with well developed microvilli and digestive enzymes on the apical membrane [52]. These cells can be grown and differentiated on polycarbonate microporous filters (Transwell ${ }^{\circledR}$ ), allowing the separation of apical from basolateral compartments, reproducing the in vivo organisation of the intestinal mucosa, where the apical surface corresponds to the intestinal lumen, and the basolateral surface corresponds to the surface of interstitial space and the vascular and lymphatic systems [70]. The IPEC- 1 cell line is a newborn swine intestinal cell line derived from the small intestine of a newborn unsuckled piglet that can differentiate in culture and exhibit enterocytic features, including microvilli and tight junctions $[6,23]$. They are less characterised than Caco- 2 cells and have been less extensively used.

\section{THE COMPLEX INTERACTION AMONG EPITHELIAL CELLS, INTESTINAL IMMUNE CELLS AND MICROFLORA FOR GUT PROTECTION}

The intestine has an enormous surface continuously exposed to a myriad of antigens, toxic compounds and bacteria, and thus is more susceptible to inflammatory response. A continuous and fine interaction between the enterocytes, microflora and gut immune system is fundamental to maintain correct cell functioning and to protect the cells against aggression from the external environment [84, 90]. Dysfunction of any component of this highly integrated mucosal system may lead to a disruption in communication and result in pathological inflammation.

\subsection{The intestinal epithelium as a mucosal barrier}

The intestinal epithelium constitutes the major barrier that separates the external from the internal environment and represents the first line of defence against pathogens and dangerous environmental agents. The major role in regulating epithelial permeability and avoiding the entry of external molecules is played by tight junctions. They encircle the cells at the apical end of the lateral membrane and are composed of an array of proteins, including an integral membrane protein, the occludin, and cytosolic peripheral membrane proteins, the zonula occludens proteins (ZO-1, ZO-2). These proteins are in close apposition to the actin and myosin ring, in a dynamic adaptation to a variety of developmental, physiological and pathological circumstances [71]. The mucosal barrier can be destroyed in some diseases and by some pathogens, allowing the indiscriminate passage of luminal antigens across the epithelial junctions. The mucus layer, composed of glycoconjugates and intestinal mucins [22], is localised on the cellular surface of the intestinal epithelium and contributes to cell defence creating a physical barrier and avoiding bacterial adhesion through glycoconjugates. Another defence mechanism against toxic substances and microorganisms is represented by proteins produced by mucosal intestinal cells, such as the "trefoil" proteins [14] and defensins [91].

\subsection{Mucosal immunity}

The intestinal mucosa is provided with one of the largest immunological organs of the body which, through complex mechanisms, is able to remove pathogens, eliminate infected cells and develop an immunological memory to induce a more rapid response against a subsequent exposure to the same antigens. The gut-associated lymphoid tissue (GALT) comprises follicles or groups of them defined as Peyer's patches, surrounded by specialised $\mathrm{M}$ cells, responsible for the transport in the patches of antigens and bacteria coming from the intestinal lumen [44, 57, 77]. The GALT also includes diffuse lymphoid tissue in the lamina propria, intraepithelial lymphocytes, 
mesenteric lymph nodes and an appendix. After antigen presentation by antigen presenting cells, lymphocytes leave the Peyer's patches (inductive sites of the intestinal mucosa), and migrate to effector sites, such as the spleen, lungs, respiratory and urogenital tracts. At intestinal sites, lymphocytes are recruited and spread in the lamina propria to produce antibodies (mainly IgA) or migrate into the epithelium. The intestinal immune system must protect the mucosa against pathogens and noxious substances, but has to be able to avoid hypersensitivity reactions against food proteins, normal microflora and innocuous macromolecules present in the intestine. It is known that reactions against food have an immunological basis and can derive from a breakdown of tolerance to microflora or food antigens $[20,78]$. This may lead to the development of intestinal immune pathologies directed against autoantigens and therefore to autoimmune diseases.

\subsection{Gut microflora}

The intestinal microflora helps the host to fight the colonisation of pathogenic bacteria and to protect against dangerous substances arriving in the colon. The embryo intestine is sterile, and the gastrointestinal colonisation starts after delivery. In one year, the microflora becomes similar to the adult one. During life, microflora composition can transiently change in response to diet, health conditions and the environment [2]. Enteric pathogens may cause several damages to intestinal cells, including interference in the epithelial cell signalling that controls both the transcellular and paracellular secretion pathways [84]. Microflora contributes to intestinal protection against pathogens by competition for pathogen binding sites, regulation of immune response, competition for nutrients, production of antimicrobial substances, such as bacteriocins, generation of restrictive physiological conditions, such as acidic $\mathrm{pH}$ caused by lactobacilli fermentations and by short chain fatty acid (SCFA) production [79].

\section{ALTERNATIVES TO IN-FEED ANTIBIOTICS}

\subsection{Probiotics}

Recently, probiotics have been defined as "a preparation or a product containing viable, defined microorganisms in sufficient number, which alter the microflora (by implantation or colonisation) in a compartment of the host, and by that exert beneficial health effects on the host" [73]. This implies that probiotics should be able to survive to gastric juice and bile salts and that an adequate dose is necessary to have beneficial effects. The most known characteristics of probiotics are the following: a capacity to adhere to intestinal mucosa and to inhibit pathogen adhesion, ability to transiently colonise and proliferate in the intestine, prevention of some intestinal diseases such as diarrhoea, modulation of the immune system of the host, anticancer activity, and a capacity to lower cholesterol level and reduce lactose intolerance [79].

The description of all these characteristics is not the purpose of this review, which will focus on the ability of probiotics to protect the intestinal cells against pathogens and avoid inflammatory processes.

\subsubsection{Prevention of intestinal disease}

Infection by ETEC is one of the principal causes of diarrhoeal disease in pigs during the pre- and post-weaning period, and among the different ETEC strains, those expressing K88 fimbrial adhesins are the most prevalent [27]. The pathogenic action of ETEC is exerted through the binding of K88 fimbriae to specific intestinal receptors, allowing the release of enterotoxins which induce massive fluid and electrolyte secretion, resulting in diarrhoea. Diarrhoea may also arise as a consequence of antibiotic treatment [81], which may cause an imbalance in intestinal microflora, leading to an increase of some pathogenic bacteria, with consequent diarrhoea symptoms, due to toxin release. 
Probiotics may represent an important mean to overcome these problems. The rationale for probiotic use is that probiotics are able to restore normal microflora. Only a few probiotics have been tested for their capacity to prevent intestinal diseases in pigs. Some authors have found that oral administration of Streptococcus faecium to gnotobiotic piglets challenged with various pathogenic strains of $E$. coli induces an increased weight gain, less severe diarrhoea and a reduced colonisation of pathogenic bacteria in the gut compared to control animals $[82,83]$.

A protective effectiveness of Bifidobacterium lactis has been found in piglets where lower concentrations of fecal rotavirus and E. coli and a lower severity of diarrhoea have been associated with probiotic treatment [75]. Similarly, feed supplemented with Bacillus toyoi or B. licheniformis, reduce the incidence and severity of diarrhoea [36], as well the number of enterococci and coliforms, especially ETEC in the intestines $[1,36]$.

Beside these studies, there are no indications on how such effects were achieved. In an attempt to understand some of the possible mechanisms involved in the beneficial effect of probiotics, we have conducted experiments on both human and porcine intestinal cells treated with different strains of probiotics. In a study on Caco- 2 cells differentiated on Transwell filters, we investigated the protective effect of Bifidobacterium animalis MB5 and Lactobacillus casei GG against the membrane damage induced by ETEC K88 [67]. The integrity and functional sealing of tight junctions were monitored by measuring the transepithelial electrical resistance (TEER) of the cell monolayer. The results showed that these probiotics do not affect the TEER nor prevent the ETECinduced permeability increase when added together with ETEC.

In another study on porcine IPEC-1 cells, we found that ETEC K88 induced a TEER decrease and disruption of tight junctions as well as a disorganisation of the cytoskeleton and tight junction structure [Mengheri et al., unpublished data]. The TEER alteration was not prevented by treatment with two Lactobacillus amylovorus strains: one belonging to L. amylovorus-like strains [38], the pLAI strain isolated from the pig small intestine (Konstantinov et al., unpublished data) and L. amylovorus DSMZ (commercial strain isolated from cattle waste). However, $p L A I$ was able to protect the cytoskeleton and tight junction organisation by maintaining a correct localisation of occludin and $\beta$-actin suggesting that, despite the TEER decrease, $p L A I$ can protect the intestinal permeability from the perturbation induced by ETEC K88. Moreover, these data indicate a strainspecific effect. Our results were partly in agreement with those reported recently on T84 or HT-29 cell lines where a mixture of lactobacilli, bifidobacteria and streptococci (VSL\#3) or L. acidophilus were able to stabilise tight junctions [49, 55].

Using a model of pigs challenged with the same strain of ETEC K88 used in our in vitro experiments [8], Bosi et al. confirmed the beneficial effect of $p L A I$, since the daily weight gain increased and there was a trend towards an increase in ETEC K88 shedding and total IgA in saliva and serum [unpublished results].

\subsubsection{Inhibition of pathogen adhesion}

There is some evidence in pigs that probiotics can inhibit pathogen adhesion. Some authors have found that E. faecium, one of the probiotic strains most frequently found in swine intestine [17], is able to inhibit the adhesion of ETEC K88 to the intestinal mucus of piglets, where receptors for adhesive fimbriae of ETEC K88 are present [33]. They reported that ETEC and E. faecium do not attach to the same domain of the receptor, and therefore they conclude that the inhibition of ETEC adhesion is likely due to steric hindrance.

Other experiments using lactobacilli have indicated that these bacteria reduce the 
adhesion of pathogenic bacteria in the intestine of gnotobiotic piglets but only if maltodextrin was also administered [5].

The adhesion to intestinal cells has been proposed as one of the main selection criteria for probiotic strains since, throughout this capacity, probiotics have been thought to compete for pathogen adhesion. Several studies have been conducted in vitro to test the ability of different probiotic strains to adhere to intestinal cells. A study on Caco2 cells reports the results relating the adhesion of 30 strains of lactic acid bacteria of the species Lactobacillus and Bifidobacterium [51]. The bacteria adhered in a strain dependent manner to the cells, and L. rhamnosus strain GG exhibited the strongest affinity for Caco-2 cells. Also $L$. casei, $B$. bifidum and $B$. adolescentis showed a relatively high affinity for Caco- 2 cells. Interestingly, contact with lactobacilli did not result in the production of pro-inflammatory cytokines interleukin (IL)-6 and IL-8, and bifidobacteria induced a slight production of these cytokines, indicating that these bacteria do not trigger an inflammatory response after their adhesion to enterocytes.

The inhibition of adhesion of diarrhoegenic bacteria, such as Salmonella typhimurium, Yersinia pseudotubercolosis, Listeria monocytogenes and E. coli to Caco-2 and HT-29 cells by the L. acidophilus strain LB $[13,16]$ and strain LA1 [3] has been reported by some authors suggesting that competitive exclusion is the cause of such inhibition, since the heat killed-bacteria maintained the inhibitory ability.

Other authors have suggested that steric hindrance is not a mechanism of adhesion inhibition [40]. They found an inhibition of S. typhimurium adhesion to Caco- 2 cells by L. case $i \mathrm{GG}$, but not when this probiotic was incubated with Caco-2 cells before $S$. typhimurum addition. They suggested that L. casei is unable to block the binding sites for $S$. typhimurum adhesion by steric hindrance. They also found a reduced adhesion with spent culture supernatant at low $\mathrm{pH}$, and suggested the importance of $\mathrm{pH}$ as an inhibitory factor of pathogen adhesion. The hypothesis that steric hindrance may account for the inhibition of bacterial adhesion by probiotics has also been argued by other authors, reporting that the level of adhesion of ETEC, enteropathogenic E. coli (EPEC) and Klebsiella pneumoniae was much higher than that of L. casei rhamnosus, when the same number of bacteria were added to the cells [21].

An antagonistic activity against adhesion and invasion of ETEC on Caco- 2 and HT-29 cells by spent culture supernatant of L. rhamnosus and B. lactis has also been reported in other studies [24]. Since the molecules secreted by these probiotics in the medium were affected by lactate dehydrogenase, trypsin and proteinase $K$, the results indicated a synergistic action of lactic acid and proteinaceous substances.

Some authors, using the HT-29 cell-line secreting mucus infected with EPEC, found an inhibition in the attachment of bacteria to the cells by L. plantarum and L. rhamnosus GG, which was associated with an induction of mucin gene expression (MUC-2 and MUC-3). They proposed that the increase in intestinal mucins is responsible for the probiotic inhibitory activity [43]. Other studies report an increase of MUC-2, MUC3 and MUC-5AC in HT-29 cells by VSL\#3 [55] and an up-regulation of MUC-2 expression in Caco-2 cells by L. casei GG [47].

In recent studies, we have found that ETEC K88 adheres to Caco-2 cells and that treament with $B$. animalis is able to reduce this adhesion. Moreover, when B. animalis and $L$. case $i$ were assayed for their ability to reduce ETEC invasivity, we found an inhibition of ETEC internalisation [67]. These results indicate that, despite the lack of protection on membrane permeability described above, probiotics are able to protect cells against ETEC infection.

A protection against the adhesion of ETEC K88 was also observed on IPEC-1 cells treated with the two $L$. amylovorus strains, mentioned above. We found that 
the ETEC adhesion was reduced only by pLAI and not by L. amylovorus DSMZ, suggesting again a strain-specificity, in agreement with the results observed on cytoskeleton and tight junction proteins, where a protection was found only with $p L A I$ [Roselli et al., unpublished data].

\subsubsection{Immunomodulation}

Probiotics are able to prevent intestinal diseases through, both humoral and cellmediated immune modulation [19]. Indeed, it has already been shown that probiotics may lead to an increased IgA production [59] and stimulation of macrophage and NK activity $[15,46]$. Moreover, several studies have reported that probiotics are able to regulate both anti- and pro-infammatory cytokine production. However the results are quite conflicting and the mechanisms of action of probiotics on cytokine expression are still not understood.

In pigs, weaning is associated with a transient inflammatory response in the gut, as indicated by the up regulation of several inflammatory cytokines, such as IL-1 $\beta$, tumour necrosis factor (TNF)- $\alpha$ and IL-6 [60], which might be implicated in the development of post-weaning diarrhoea. Some studies reported that treatment of piglets with $B$. lactis increases blood leukocyte phagocytic and T-lymphocyte proliferative responses [75]. Similar results have been observed with gnotobiotic piglets, where feeding with $L$. acidophilus increases the white blood cells [61] and the antibody level [41].

In vitro experiments have put some light on the molecular basis for the reduction of inflammation by probiotics. Indeed, some authors have indicated that the VSL\#3 mixture of probiotics ameliorates inflammatory responses in HT-29 cells by reducing IL-8 expression [55]. A reduction of IL-8 has also been found in HT-29 cells in response to Salmonella dublin stimulus by using VSL\#3 DNA, suggesting that the DNA of probiotic bacteria is responsible for such activity [32].
Some authors, using a co-culture of Caco-2 cells with peripheral blood lymphocytes, have indicated that the reactivity of intestinal cells to probiotics is dependent on the presence of immunocompetent cells. Indeed, they found that Caco-2 cells alone are hyporesponsive to challenge with non-pathogenic E. coli and L. sakei. On the contrary, when cultured with leukocytes, Caco- 2 cells produce TNF- $\alpha$ and IL- $1 \beta$ after treatment with $L$. sakei, but also the antiinflammatory transforming growth factor (TGF)- $\beta$ after L. johnsonii treatment [26].

To clarify the mechanisms by which probiotics can prevent or reduce the development of inflammatory processes, we investigated whether the recruitment of neutrophil migration to inflammatory sites, as well as the expression of chemokines involved in neutrophil infiltration and that of pro- and anti-inflammatory cytokines were regulated by probiotic treatment. We have shown that the inflammatory response induced by ETEC involves a strong increase of neutrophil transmigration, as tested on Caco- 2 cells differentiated on inverted monolayers. This migration was markedly reduced when B. animalis or L. casei GG were added together with ETEC, and this was associated with a decreased expression of chemokines IL-8, growth related oncogene (GRO)- $\alpha$ and epithelial neutrophil-activating protein (ENA)-78 [68]. Moreover, we have also found that probiotics are able to reduce the ETEC-induced increased expression of pro-inflammatory IFN- $\gamma$ and TNF- $\alpha$, and to increase that of anti-inflammatory TGF- $\beta$ [67]. All these results suggest that probiotics interfere with different steps of the inflammatory pathway, either on cytokines that can regulate the balance between Th1 and Th2 lymphocyte populations, or on chemokines involved in the recruitment of inflammatory cells.

\subsection{Zinc}

Zinc is an abundant trace element in the body that is involved in a variety of general 
cellular functions, including replication, transcription and signal transduction [85]. It is important for the formation of biomembranes and zinc finger motifs found in DNA transcription factors and exerts catalytic function in metalloenzymes. Thus, zinc regulates the homeostatic balance of multiple physiological processes. The daily zinc requirement is mainly provided by food intake and the gastrointestinal tract is the primary absorptive and secretory site for zinc. Dietary inadequacy or conditions that alter zinc absorption in the gastrointestinal tract may quickly cause zinc deficiency, due to the limited availability of rapidly exchangeable zinc pools [39]. The unique role of the gastrointestinal system in zinc metabolism places it at a critical position to control zinc homeostasis.

\subsubsection{Maintenance of barrier integrity}

The importance of zinc in maintaining the epithelial barrier integrity and function has already been established [85]. Previous in vivo and in vitro studies have shown that zinc deficiency induces ulcerations to intestinal villi [53] and alters the barrier function of porcine endothelial cells [28], whereas treatment of these cells with zinc gives protection against TNF- $\alpha$ induced disruption of the cell monolayer [29].

Several studies conducted on piglets have shown that supplementation of high doses of $\mathrm{ZnO}$ (3000 $\mathrm{mg}$ per $\mathrm{kg}$ ) improves small intestine morphology, by increasing the villous height to crypt depth ratio, compared to pigs fed the same diet without $\mathrm{ZnO}$ supplementation $[11,42]$. The positive effect of $\mathrm{ZnO}$ on villous height was also observed when weaning pigs were orally challenged with ETEC [11, 42] or with transmissible gastroenteritis (TGE) virus [76].

The rationale of all these studies was that $\mathrm{ZnO}$ is the best zinc source for improving pig growth and performance [25], and that $\mathrm{ZnO}$ may inhibit the growth of some bacterial species [72]. However, these studies did not investigate whether the effect of zinc supplementation is dependent on the physiological conditions of the cells and on the presence of inflammation induced by bacteria, and whether this effect is associated with a decrease of bacterial infection. Indeed, some authors did not find a reduced number of $E$. coli in the faeces of pigs treated with $\mathrm{ZnO}[31,35]$.

In recent studies, we have shown that treatment of Caco- 2 cells with $\mathrm{ZnO}$ is able to protect enterocytes from the membrane damage induced by ETEC K88 infection through mechanisms that are not ascribable to an antibacterial activity of $\mathrm{ZnO}$ [69]. We have reported that various concentrations of $\mathrm{ZnO}$ (from 0.01 to $5 \mathrm{mM}$ ) did not affect tight junction permeability of Caco-2 cells, measured as TEER and ${ }^{14} \mathrm{C}$-inulin transfer, after several hours and even days of culture. On the contrary, treatment of cells with ETEC increased tight junction permeability and $\mathrm{ZnO}$ was able to inhibit the ETECinduced membrane damage, in a time and dose dependency, and was effective already at a low level $(0.2 \mathrm{mM}$, that is 20 times higher than that of the culture medium). To understand whether the protective effect of $\mathrm{ZnO}$ was due to killing of bacteria, the growth of ETEC in the presence of several concentrations of $\mathrm{ZnO}$ was tested. The resulting bacterial growth was unaffected by $\mathrm{ZnO}$, indicating that the protective action of $\mathrm{ZnO}$ was not due to its supposed antibacterial activity. It has been hypothesised that the modulation of inflammatory cytokines by $\mathrm{ZnO}$ could play a role in maintaining tight junction function and structure [54]. Indeed, it has been shown that TNF- $\alpha$ can act synergistically with IFN- $\gamma$ to induce structural changes in tight junctions, whereas TGF- $\beta$ upregulates barrier function and counteracts the IFN- $\gamma$ effect [88]. Moreover, it is known that cytokines are extremely sensitive to the amount of zinc present in the cells $[9,62]$. The findings that $\mathrm{ZnO}$ prevents the ETEC-induced increase of inflammatory cytokines in Caco- 2 cells, as described below (see Zinc and intestinal immune response), support this new role of zinc in 
regulating the tight junction function through the regulation of cytokines.

In agreement with these findings, in experiments conducted in vivo on piglets challenged with ETEC K88, Bosi et al. [7] have indicated that supplementation with $\mathrm{ZnO}$ at low and high doses of zinc (200 and $2500 \mathrm{mg}$ per $\mathrm{kg}$ ), induces a positive effect on the villous height of the jejunum, which is independent of the dose of zinc. They have also found that supplementation with zinc chelated with glutamate at the same low and high dose of $\mathrm{ZnO}$, induces similar morphological effects. Further experiments should be done to better investigate the potential benefits of zinc glutamate.

\subsubsection{Protection against pathogens}

Zinc is essential in the prevention of pathogen infection [74]. A condition of zinc deficiency, which causes an impairment of immune response [62], is associated with a great incidence of infectious diseases, including diarrhoea [89], in a synergistic and self perpetuating manner. Indeed, nutrient absorption is reduced during diarrhoea, due to the deterioration of absorptive mucosa. Moreover, the increase of intestinal bacteria or the undigested solids generated during the disease can absorb minerals, including zinc, reducing their bioavailability. Thus, zinc can be insufficient for mucosal regeneration perpetuating the pathology.

Zinc supplementation has been shown to prevent or alleviate diarrhoea in piglets [30, $31,56]$, to maintain stable levels of the intestinal flora and diverse coliforms that may compete with diarrhoegenic strains for colonisation sites [35] and to reduce translocation of pathogenic bacteria from the small intestine to the mesenteric lymph nodes [30]. However, Li et al. [41] did not observe any effect on the microflora collected from the digesta and faeces of piglets after 11 days of high dose $\mathrm{ZnO}$ supplementation. Moreover, Mores et al. [50] registered an improvement of diarrhoea index in E. coli $\mathrm{K} 85$ infected pigs fed $2400 \mathrm{mg}$ per $\mathrm{kg}$ zinc from different commercial sources of $\mathrm{ZnO}$, but did not observe any reduction of faecal shedding of the strain used for the challenge. Despite the controversial results on the reduction of diarrhoea associated with the growth promoting effect of $\mathrm{ZnO}$, there is sufficient evidence for a protective activity of $\mathrm{ZnO}$ against pathogens.

In an attempt to understand whether the inhibition of bacterial adhesion by zinc would be fundamental for preventing the development of bacterial disease, in a recent study, we investigated whether $\mathrm{ZnO}$ could reduce ETEC K88 adhesion in Caco-2 cells [69]. We found that the addition of 0.2 and $1 \mathrm{mM} \mathrm{ZnO}$ induced a significant reduction of bacterial adhesion as compared to infected cells, but $0.05 \mathrm{mMZnO}$ was ineffective. We suggest that the reduction of ETEC adhesion by $\mathrm{ZnO}$ treatment could be due to the binding of this metal to bacterial fimbriae, that interfers with ETEC recognition by the specific receptors on intestinal cells, since it has been shown that the fimbriae of $E$. coli are able to exclusively bind the oxide form of zinc [33].

Since we have found that ETEC K88 induces a disruption of the epithelial barrier, as described above, we have hypothesised that in this condition ETEC could invade the cells and that $\mathrm{ZnO}$ could be able to protect the cells from this invasion. Indeed, we found an internalisation of ETEC into the Caco- 2 cells after $2 \mathrm{~h}$ of infection, when the tight junctions were damaged, and an inhibition of bacterial entry by 0.2 and $1 \mathrm{mM}$ $\mathrm{ZnO}$ treatment [69].

The studies conducted by Bosi et al. [7] on piglets challenged with ETEC K88 have confirmed a protective effect of $\mathrm{ZnO}$ against this bacterium, since supplementation with high doses of $\mathrm{ZnO}$ (2500 $\mathrm{mg} \mathrm{Zn}$ per $\mathrm{kg}$ ) was able to reduce the number and faecal excretion of ETEC K88, but there was only a trend towards a reduction of diarrhoea score. Similar effects were also found after zinc-glutamate supplementation. Thus, there is the possibility that other chemical forms 
of zinc can protect the intestine from ETEC infection.

\subsubsection{Regulation of the intestinal immune response}

There is large evidence that zinc plays a fundamental role in the regulation of immune response. This evidence comes from several studies showing that zinc deficiency affects both humoral and cellular immunity. Zinc supplementation has, however, been shown to improve the immune response in some conditions [62].

The effect of zinc supplementation has been studied in piglets by some authors who reported an enhanced macrophage function with a combination of zinc lysine and zinc methionine and with $160 \mathrm{ppm}$ of zinc from zinc sulphate [86].

In other studies it has been demonstrated that dietary zinc over the minimal requirements (50 to $150 \mathrm{ppm}$ ) stimulated an enhanced fever response to LPS [66]. This could be related to an increased release of inflammatory cytokines. Indeed, the activity of monocytes, that are important producers of TNF, is strongly stimulated at high plasma zinc concentrations [64].

In a recent study on Caco- 2 cells infected with ETEC, we investigated whether a dysregulation of cytokines contributes to the damage induced by this bacterium, and whether treatment with $\mathrm{ZnO}$ could prevent these alterations [69]. The results showed that ETEC induce a dramatic increase in IL-8, GRO- $\alpha$ and TNF- $\alpha$ mRNA and a decrease of TGF- $\beta$ mRNA, whereas the expression of these cytokines after $\mathrm{ZnO}$ treatment were at a normal level. Since $\mathrm{ZnO}$ was able to only partially inhibit bacterial adhesion (see above), these results suggest that $\mathrm{ZnO}$ affected the synthesis of cytokine mRNA by likely interfering with the stimulus of the adhered bacteria to induce cytokine synthesis.

However, studies on pigs challenged with ETEC K88 and supplemented with $\mathrm{ZnO}$ or zinc glutamate did not indicate any change on the cytokines of mesenteric lymphocytes between zinc treated and untreated pigs [Roselli et al., unpublished data]. A possible explanation for the different results obtained in vitro and in vivo on cytokine regulation can be that mesenteric lymphocytes are not the target for zinc supplementation, whereas the enterocytes may have been influenced by zinc supplementation with a consequent cytokine modulation.

Bosi et al. [7] have found that in weaning pigs challenged with ETEC K88, zinc supplementation (2500 $\mathrm{mg} \mathrm{Zn} \mathrm{per} \mathrm{kg}$ ) did not change total $\operatorname{IgA}$ in saliva, blood and intestinal secretion. However, a trend towards a reduction of K88-specific IgA was observed in serum and in saliva after $\mathrm{ZnO}$ and zinc glutamate supplementation. These data indicate that zinc treatment did not affect the $\operatorname{IgA}$ secretory response, and that the recruitment of specific immune cells is reduced, likely due to a diminished presence or activity of ETEC.

\subsection{Organic acids}

Hydrochloric acid secreted by the stomach acts as an antimicrobial molecule and contributes to the gut barrier against pathogens. However, at weaning, natural acidification is reduced after the interruption of milk suckling and acid secretion is slightly increased after the first contacts with the creep feed. Furthermore, the standard sources of minerals used in high quantity to satisfy the requirements of very young pigs have high acid buffering capacity [4]. If acid secretion cannot be improved by the diet, dietary addition of organic acids may help to increase the control of microorganisms in the stomach and, afterwards, in the intestine.

However, some caution is required for the use of acidifiers, since there are some indications of development of acidic resistance of S. typhimurium and E. coli after exposure to SCFA [63].

\subsubsection{Protection from intestinal damage}

Some authors showed that during an outbreak of post-weaning diarrhoea, various 
organic acids were able to reduce the incidence and severity of diarrhoea and exclude the presence of ETEC K88 in the intestine at the end of the experiment [80]. On the contrary, other authors did not observe any positive effect of feeding organic acids on diarrhoea score in ETEC K88 challenged pigs [65]. A meta-analysis of growth performance of piglets from 35 published experiments, predicted that formic acid, formate salts, fumaric acid and citric acid (in the range 80-400 mEquiv per $\mathrm{kg}$ ) improved growth and feed efficiency [58]. Knarreborg et al. [37], using a batch culture system containing intestinal contents from the pig, showed an inhibitory effect of an organic acid (K-diformate) on the growth of coliform bacteria, independent of the $\mathrm{pH}$ used, and a small reduction in growth rate of lactic acid bacteria at $\mathrm{pH} 5$.

The effect of acidifiers on microflora is usually similar in the stomach and in the small intestine [10]. Thus, it can be difficult to assess whether the control of microflora observed in the small intestine is indeed a result of the effect of organic acid in the stomach. The use of slow release acidifiers may avoid the effects of a gastric environment. Mazzoni et al. [48] found that feeding fat-coated calcium formate did not reduce the number of gastric parietal cells of piglets, as did the same quantity of supplementation with free calcium formate. They found, however, that in ETEC K88-challenged weaning pigs the incidence and severity of diarrhoea was reduced with both forms of calcium formate. Furthermore, the average villous height of the small intestine increased with both formate additions. However, the improvement of growth performance was stronger with free formate than with a protected acidifier. It cannot be excluded that fat coating formate was unsufficiently digested and thus the formate not fully available.

In experiments on Caco-2 and IPEC-1 cells, we tested the protective effect of some organic acids against ETEC K88 [Mengheri et al., unpublished data]. We found that
Ca-formate $(30 \mathrm{mM})$ was able to protect Caco- 2 cells from the TEER decrease induced by the pathogen. Moreover, we found that treatment of undifferentiated IPEC-1 cells with Na-butyrate $(2 \mathrm{mM})$ induced a TEER increase and established a tight junction structure, as indicated by the fluorescence localisation of occludin and ZO-1 proteins. These data are in agreement with previous studies showing that butyrate can induce a differentiation status on some cell lines [45]. However, we found that this treatment did not protect the cells from the membrane damage induced by ETEC K88.

\subsubsection{Immune response}

SCFA, such as propionate and butyrate, seem to modulate the expression of genes that favour the invasion of various Salmonella spp. in the enterocyte [18, 87]. It has not yet been verified if other pathogens are sensitive to these organic acids and if other acidifiers have these specific properties.

Bosi et al. [unpublished results] reported that in ETEC K88-challenged weaning pigs, total IgA in saliva was reduced by dietary calcium formate, suggesting that the organic acid was able to reduce the number of local bacteria. This effect was not confirmed for total IgA blood serum and jejunum secretions. This could be explained by a different composition of intestinal microflora, compared to mouth microflora. Further experiments are necessary to clarify why these organic acids gave different responses.

An immunomodulatory effect by SCFA has been reported by some authors in HT-29 and Caco- 2 cells. They found that butyrate, acetate and propionate induces an up-regulation of IL-18 expression, which is implicated in Th1 cell-mediated chronic inflammation [34]. Contrasting results have been found by other authors, reporting that a combination of butyrate, acetate and propionate causes a shift in the T helper lymphocyte phenotype towards the anti-inflammatory phenotype [12]. 


\section{CONCLUSIONS}

Although some results are controversial, it appears from the data presented that all the alternatives to in-feed antibiotics considered may exert protective effects on intestinal cells from the damage induced by pathogenic bacteria. The in vitro results have highlighted some mechanisms underlying the activities of these alternatives. For example, they indicate that the protective activity of probiotics against pathogens are not merely due to inhibition of adhesion, that for a long time it has been considered one of the principal causes of this protection. Furthermore, they show that the protection of $\mathrm{ZnO}$ is not due to its supposed antibacterial activity. The studies reported here suggest that in-feed alternatives may protect the cells against the pathogenic attack through a series of mechanisms, including the inhibition of adhesion and invasion of pathogens, interference of the signalling pathway of pathogenic bacteria, maintenance of epithelial cell cytoskeleton and junctional structure and modulation of the host immune response.

The better knowledge of the mechanisms of action of alternatives to in-feed antibiotics is clearly important in order to establish their impact on intestinal cells, and may thus be useful to select those that can have a protection on weaning pigs.

A reduction of high dose supplementation of heavy metals, such as zinc, has been recommended by the European Community. The studies reported here indicate that $\mathrm{ZnO}$ remains a valid alternative to in-feed antibiotics and that it may exert a protective effect even at moderate doses, as supported by some in vivo data. Considering the various mechanisms of action of $\mathrm{ZnO}$, our findings suggest that further in vivo experiments may be done to find a low dose of $\mathrm{ZnO}$ supplementation able to induce beneficial effects in piglets, as proven by a wider array of health status parameters than those used up to now. This may contribute to reduce environmental pollution by high doses of zinc in the nature.

\section{ACKNOWLEDGEMENTS}

The European Community is greatly acknowledged for financial support of the project HEALTHYPIGUT (contract No. QLK5-CT 2000-00522). The authors are solely responsible for this text which does not represent the opinion of the $\mathrm{EC}$ and the $\mathrm{EC}$ is not responsible for the information delivered.

\section{REFERENCES}

[1] Adami A., Cavazzoni V., Occurrence of selected bacterial groups in the faeces of piglets fed with Bacillus coagulans as probiotic, J. Basic Microbiol. 39 (1999) 3-9.

[2] Akkermans A.D.L., Konstantinov S.R., Zhu W.Y., Favier C.F., Williams B.A., Postnatal development of the intestinal microbiota in pig, in: Ball R.O. (Ed.), Proceedings of the 9th International Symposium on Digestive Physiology in Pigs, Banff, AB, Canada, 2003, pp. 49-56.

[3] Bernet M.F., Brassart D., Neesr J.R., Servin A.L., Lactobacillus acidophilus LA1 binds to cultured human intestinal cell lines and inhibits cell attachment and cell invasion by enterovirulent bacteria, Gut 35 (1994) 483-489.

[4] Bolduan G., Jung H., Schneider R., Rye and wheat in piglet rations supplemented by bisergon, Arch. Tierernahr. 38 (1988) 183-191.

[5] Bomba A., Nemcova R., Gancarcikova S., Herich R., Kastel R., Potentiation of the effectiveness of Lactobacillus casei in the prevention of $E$. coli induced diarrhea in conventional and gnotobiotic pigs, Adv. Exp. Med. Biol. 473 (1999) 185-190.

[6] Bouhet S., Hourcade E., Loiseau N., Fikri A., Martinez S., Roselli M., Galtier P., Mengheri E., Oswald I.P., The mycotoxin, fumonisin $\mathrm{B}_{1}$ alters the proliferation and the barrier function of porcine intestinal epithelial cells, Toxicol. Sci. 77 (2004) 165-171.

[7] Bosi P., Merialdi G., Sarli G., Casini L., Gremokolini C., Preziosi R., Brunetti B., Trevisi P., Effects of doses of $\mathrm{ZnO}$ or $\mathrm{Zn}$ Glutamate on growth performance, gut characteristics, health and immunity of earlyweaned pigs orally challenged with $E$. coli K88, in: Proceedings of the A.S.P.A., 15th Congress, Parma, Ital. J. Anim. Sci. 2 (2003) 361-363.

[8] Bosi P., Gremokolini C., Trevisi P., Mazzoni M., Bonilauri P., Sarli G., Casini L., La stimulation orale par E. coli K88 comme méthode 
d'évaluation des performances de croissance et de l'état de santé des porcelets sevrés dans les études expérimentales d'alimentation, Journées Recherche Porcine 36 (2004) 125132.

[9] Canali R., Vignolini F., Nobili F., Mengheri E., Reduction of oxidative stress and cytokineinduced neutrophil chemoattractant (CINC) expression by red wine polyphenols in zinc deficiency induced intestinal damage of rat, Free Radic. Biol. Med. 28 (2000) 1661-1670.

[10] Canibe N., Steien S.H., Overland M., Jensen B.B., Effect of K-diformate in starter diets on acidity, microbiota, and the amount of organic acids in the digestive tract of piglets, and on gastric alterations, J. Anim. Sci. 79 (2001) 2123-2133.

[11] Carlson M.S., Hoover S.L., Hill G.M., Link J.E., Turk J.R., Effect of pharmacological zinc on intestinal metallothionein concentration and morphology in nursery pig, J. Anim. Sci. 76 (1998) 53.

[12] Cavaglieri C.R., Nishiyama A., Fernandes L.C., Curi R., Miles E.A., Calder P.C., Differential effects of short-chain fatty acids on proliferation and production of pro- and antiinflammatory cytokines by cultured lymphocytes, Life Sci. 73 (2003) 1683-1690.

[13] Chauviere G., Coconnier M.H., Kerneis S., Darfeuille-Michaud A., Joly B., Servin A.L., Competitive exclusion of diarrheagenic Escherichia coli (ETEC) from human enterocyte-like Caco-2 cells by heat killed Lactobacillus, FEMS Microbiol. Lett. 70 (1992) 213217.

[14] Chen Z.W., Bergman T., Ostenson C.G., Efendic S., Mutt V., Jornvall H., Characterization of dopuin, a polypeptide with special residue distributions, Eur. J. Biochem. 249 (1997) 518-522.

[15] Chiang B.L., Sheih Y.H., Wang L.H., Liao C.K., Gill H.S., Enhancing immunity by dietary consumption of a probiotic lactic acid bacterium (Bifidobacterium lactis HN019): optimization and definition of cellular immune responses, Eur. J. Clin. Nutr. 54 (2000) 849-855.

[16] Coconnier M.H., Klaenhammer T.R., Kerneis S., Bernet M.F., Servin A.L., Protein-mediated adhesion of Lactobacillus acidophilus BG2FO4 on human enterocyte and mucussecreting cell lines in culture, Appl. Environ. Microbiol. 58 (1992) 2034-2039.

[17] Devriese L.A., Hommez J., Pot B., Haesebrouck F., Identification and composition of the streptococcal and enterococcal flora of tonsils, intestines and faeces of pigs, J. Appl. Bacteriol. 77 (1994) 31-36.

[18] Durant J.A., Corrier D.E., Ricke S.C., Shortchain volatile fatty acids modulate the expression of the hilA and invF genes of Salmonella typhimurium, J. Food Prot. 63 (2000) 573578.

[19] Erickson K.L., Hubbard N.E., Probiotic immunomodulation in health and disease, J. Nutr. 130 (2000) 403S-409S.

[20] Finamore A., Roselli M., Merendino N., Nobili F., Vignolini F., Mengheri E., Zinc deficiency suppresses the development of oral tolerance in rats, J. Nutr. 133 (2003) 191-198.

[21] Forestier C., De Champs C., Vatoux C., Joly B., Probiotic activities of Lactobacillus casei rhamnosus: in vitro adherence to intestinal cells and antimicrobial properties, Res. Microbiol. 152 (2001) 167-173.

[22] Forstner J.F., Forstner G.G., Gastrointestinal mucus, in: Johnson L.R. (Ed.), Physiology for the Gastrointestinal Tract (3rd ed.), Raven Press, New York, 1994, pp. 1255-1283.

[23] Gonzalez-Vallina R., Wang H., Zhan R., Berschneider H.M., Lee R.M., Davidson N.O., Black D.D., Lipoprotein and apolipoprotein secretion by a newborn piglet intestinal cell line (IPEC-1), Am. J. Physiol. 271 (1996) 249-259.

[24] Gopal P.K., Prasad J., Smart J., Gill H.S., In vitro adherence properties of Lactobacillus rhamnosus DR20 and Bifidobacterium lactis DR10 strains and their antagonistic activity against an enterotoxigenic Escherichia coli, Int. J. Food Microbiol. 67 (2001) 207-216.

[25] Hahn J.D., Baker D.H., Growth and plasma zinc responses of young pigs fed pharmacologic levels of zinc, J. Anim. Sci. 71 (1993) 3020-3024.

[26] Haller D., Bode C., Hammes W.P., Pfeifer A.M.A., Schiffrin E.J., Blum S., Non pathogenic bacteria elicit a differential cytokine response by intestinal epithelial cell/leukocyte co-cultures, Gut 47 (2000) 79-87.

[27] Hampson D.J., Postweaning Escherichia coli diarrhoea in pigs, in: Gyles C.L. (Ed.), Escherichia coli in domestic animals and humans, CAB International, Wallingford, UK, 1994, pp. 171-191.

[28] Hennig B., Wang Y., Ramasamy S., McClain C.J., Zinc deficiency alters barrier function of cultured porcine endothelial cells, J. Nutr. 122 (1992) 1242-1247. 
[29] Hennig B., Wang Y., Ramasamy S., McClain C.J., Zinc protects against tumor necrosis factor-induced disruption of porcine endothelial cell monolayer integrity, J. Nutr. 123 (1993) 1003-1009.

[30] Huang S.X., McFall M., Cegielski A.C., Kirkwood R.N., Effect of zinc supplementation on Escherichia coli septicemia in weaned pigs, Swine Health Prod. 7 (1999) 109-111.

[31] Jensen-Waern M., Melin L., Lindberg R., Johannisson A., Petersson L., Wallgren P., Dietary zinc oxide in weaned pigs-effects on performance, tissue concentrations, morphology, neutrophil functions and faecal microflora, Res. Vet. Sci. 64 (1998) 225-231.

[32] Jijon H., Backer J., Diaz H., Yeung H., Thiel D., McKaigney C., De Simone C., Madsen K. DNA from probiotic bacteria modulates murine and human epithelial and immune function, Gastroenterology 126 (2004) 13581373.

[33] Jin L.Z., Zhao X., Intestinal receptors for adhesive fimbriae of enterotoxigenic Escherichia coli (ETEC) K88 in swine-a review, Appl. Microbiol. Biotechnol. 54 (2000) 311-318.

[34] Kalina U., Koyama N., Hosoda T., Nuernberger H., Sato K., Hoelzer D., Herweck F., Manigold T., Singer M.V., Rossol S., Bocker U., Enhanced production of IL-18 in butyrate-treated intestinal epithelium by stimulation of the proximal promoter region, Eur. J. Immunol. 32 (2002) 2635-2643.

[35] Katouli M., Melin L., Jensen-Waern M., Wallgren P., Mollby R., The effect of zinc oxide supplementation on the stability of the intestinal flora with special reference to composition of coliforms in weaned pigs, J. Appl. Microbiol. 87 (1999) 564-573.

[36] Kyriakis S.C., Tsiloyiannis V.K., Vlemmas J., Sarris K., Tsinas A.C., Alexopoulos C. Jansegers L., The effect of probiotic LSP 122 on the control of post-weaning diarrhoea syndrome of piglets, Res. Vet. Sci. 67 (1999) 223-228.

[37] Knarreborg A., Miquel N., Granli T., Jensen B.B., Establishment and application of an in vitro methodology to study the effects of organic acids on coliform and lactic acid bacteria in the proximal part of the gastrointestinal tract of piglets, Anim. Feed Sci. Tech. 99 (2002) 131-140.

[38] Konstantinov S.R., Awati A., Smidt H., Williams B.A., Akkermans A.D.L., de Vos W.M., Specific response of a novel and abundant Lactobacillus amylovorus-like phylotype to dietary prebiotics in the guts of wean- ing piglets, Appl. Environ. Microbiol. 70 (2004) 3821-3830.

[39] Krebs N.F., Overview of zinc absorption and excretion in the human gastrointestinal tract, J. Nutr. 130 (2000) 1374S-1377S.

[40] Lehto E.M., Salminen S.J., Inhibition of Salmonella typhimurium adhesion to Caco- 2 cell cultures by Lactobacillus strain GG spent culture supernate: only a $\mathrm{pH}$ effect? FEMS Immunol. Med. Microbiol. 18 (1997) 125132.

[41] Lessard M., Brisson G.J., Effect of a lactobacillus fermentation product on growth, immune response and fecal enzyme activity in weaned pigs, Can. J. Anim. Sci. 67 (1987) 509-516.

[42] Li B.T., Van Kessel A.G., Caine W.R., Huang S.X., Kirkwood R.N., Small intestinal morphology and bacterial populations in ileal digesta and feces of newly weaned pigs receiving a high dietary level of zinc oxide, Can. J. Anim. Sci. 81 (2001) 511-516.

[43] Mack D.R., Michail S., Wei S., McDougall L., Hollingsworth M.A., Probiotics inhibit enteropathogenic E. coli adherence in vitro by inducing intestinal mucin gene expression, Am. J. Physiol. 276 (1999) G941-G950.

[44] Makala L.H., Kamada T., Nishikawa Y., Nagasawa H., Igarashi I., Fujisaki K., Suzuki N., Mikami T., Haverson K., Bailey M., Stokes C.R., Bland P.W., Ontogeny of pig discrete Peyer's patches: distribution and morphometric analysis, Pathobiology 68 (2000) 275-282.

[45] Mariadson J.M., Barkla D.H., Gibson P.R., Effect of short-chain fatty acids on paracellular permeability in Caco-2 intestinal epithelium model, Am. J. Physiol. 272 (1997) G705-G712

[46] Matsuzaki T., Chin J., Modulating immune responses with probiotic bacteria, Immunol. Cell Biol. 78 (2000) 67-73.

[47] Mattar A.F., Teitelbaum D.H., Drongowski R.A., Yongyi F., Harmon C.M., Coran A.G., Probiotics up-regulate MUC-2 mucin gene expression in a Caco-2 cell-culture model, Pediatr. Surg. Int. 18 (2002) 586-590.

[48] Mazzoni M., Lalatta Costerbosa G., Casini L., Petrosino G., Trevisi P., De Filippi S., Bosi P., La morfologia dello stomaco come parametro di valutazione dell'impiego di acidificanti nella dieta del suino in svezzamento, Atti S.I.S.Vet. 56 (2004) 240 (CD volume).

[49] Montalto M., Maggiano N., Ricci R., Curigliano V., Santoro L., Di Nicuolo F., Vecchio F.M., Gasbarrini A., Gasbarrini G., 
Lactobacillus acidophilus protects tight junctions from aspirin damage in HT-29 cells, Digestion 69 (2004) 225-228.

[50] Mores N., Cristani J., Piffer I.A., Barioni W.W.,Lima G.M.M., Efeito de oxido de zinco no controle da diarréia pós-desmane em leitões infectados experimentalmente com Escherichia coli, Arq. Bras. Med. Vet. Zoo. 50 (1998) 513-523.

[51] Morita H., He F., Fuse T., Ouwehand A.C., Hashimoto H., Hosoda M., Mizumachi K., Kurisaki J., Adhesion of lactic acid bacteria to Caco-2 cells and their effect on cytokine secretion, Microbiol. Immunol. 46 (2002) 293-297.

[52] Neutra M., Louvard D., Differentiation of intestinal cells in vitro, Mol. Cell. Biol. 8 (1989) 363-398.

[53] Nobili F., Vignolini F., Figus E., Mengheri E., Treatment of rats with dexamethasone and thyroxine protects against zinc deficiencyinduced intestinal damage, J. Nutr. 127 (1997) 1807-1813.

[54] Nusrat A., Turner J.R., Madara J.L., Molecular physiology and pathophysiology of tight junctions. IV. Regulation of tight junctions by extracellular stimuli: nutrients, cytokines, and immune cells, Am. J. Physiol. Gastrointest. Liver. Physiol. 279 (2000) G851-G857.

[55] Otte J.M., Podolsky D.K., Functional modulation of enterocytes by gram-positive and gram-negative microorganisms, Am. J. Physiol. Gastrointest. Liver Physiol. 286 (2004) G613-G626.

[56] Owusu-Asiedu A., Nyachoti C.M., Marquardt R.R., Response of early-weaned pigs to an enterotoxigenic Escherichia coli (K88) challenge when fed diets containing spray-dried porcine plasma or pea protein isolate plus egg yolk antibody, zinc oxide, fumaric acid, or antibiotic, J. Anim. Sci. 81 (2003) 1790-1798.

[57] Pabst R., Geist M., Rothkotter H.J., Fritz F.J., Postnatal development and lymphocyte production of jejunal and ileal Peyer's patches in normal and gnotobiotic pigs, Immunology 64 (1988) 539-544.

[58] Partanen K.H., MrozZ., Organic acids for performance enhancement in pig diets, Nutr. Res. Rev. 12 (1999) 117-145.

[59] Perdigon G., Alvarez S., Rachid M., Aguero G., Gobbato N., Immune system stimulation by probiotics, J. Dairy Sci. 78 (1995) $1597-$ 1606.

[60] Pié S., Lallès J.P., Blazy F., Laffitte J., Sève B., Oswald I.P., Weaning is associated with an up-regulation of expression of inflammatory cytokines in the intestine of piglets, J. Nutr. 134 (2004) 641-647.

[61] Pollmann D.S., Danielson D.M., Peo E.R., Effects of microbial feed additives on performance of starter and growing-finishing pigs, J. Anim. Sci. 51 (1980) 577-581.

[62] Prasad A.S.,Zinc, infection and immune function, in: Calder P.C., Field C.J. (Eds.), Nutrition and Immune Function, CABI publishing, 2002, pp. 193-207.

[63] Richard H.T., Foster J.W., Acid resistance in Escherichia coli, Adv. Appl. Microbiol. 52 (2003) 167-186.

[64] Rink L., Gabriel P., Zinc and the immune system, Proc. Nutr. Soc. 59 (2000) 541-552.

[65] Risley C.R., Kornegay E.M., Lindemann M.D., Wood C.M., Eigel W.N., Effect of feeding organic acids on gastrointestinal digesta measurements at various times post-weaning in pigs challenged with enterotoxigenic Escherichia coli, Can. J. Anim. Sci. 73 (1993) 931-940.

[66] Roberts E.S., Van Heugten E., Lloyd K., Almond G.W., Spears J.W., Dietary zinc effects on growth performance and immune response of endotoxemic growing pigs, Asian-Aus. J. Anim. Sci. 15 (2002) 1496-1501.

[67] Roselli M., Finamore A., Britti M.S., Mengheri E., Protective effects and immunomodulation on intestinal cells by probiotics, Proceeding of the 2nd Probiotics and Prebiotics new foods, 2003, pp. 205-212.

[68] Roselli M., Finamore A., Britti M.S., Mengheri E., Probiotic treatment is able to reduce ETEC-induced neutrophil transmigration in Caco-2 cells, Ann. Nutr. Metab. (2003) 649.

[69] Roselli M., Finamore A., Garaguso I., Britti M.S., Mengheri E., Zinc oxide protects cultured enterocytes against the damage induced by Escherichia coli, J. Nutr. 133 (2003) 40774082 .

[70] Sambuy Y., Ferruzza S., Ranaldi G., De Angelis I., Intestinal Cell Culture Models. Applications in Toxicology and Pharmacology, Cell. Biol. Toxicol. 17 (2001) 301-317.

[71] Sawada N., Murata M., Kikuchi K., Osanai M., Tobioka H., Kojima T., Chiba H., Tight junctions and human diseases, Med. Electron. Microsc. 36 (2003) 147-156.

[72] Sawai J., Quantitative evaluation of antibacterial activities of metallic oxide powders $(\mathrm{ZnO}, \mathrm{MgO}$ and $\mathrm{CaO}$ ) by conductimetric assay, J. Microbiol. Meth. 54 (2003) 177-182. 
[73] Schrezenmeir J., de Vrese M., Probiotics, prebiotics and synbiotics-approaching a definition, Am. J. Clin. Nutr. 73 (2001) 361S364 S.

[74] Scott M.E., Koski K.G., Zinc deficiency impairs immune responses against parasitic nematode infections at intestinal and systemic sites, J. Nutr. 130 (2000) 1412S-1420S

[75] Shu Q., Qu F., Gill H.S., Probiotic treatment using Bifidobacterium lactis HN019 reduces weaning diarrhea associated with rotavirus and Escherichia coli infection in a piglet model, J. Pediatr Gastroenterol. Nutr. 33 (2001) 171-177.

[76] Stanger B.R., Hill G.M., Link J.E., Turk J.R., Carlson M.S., Rozeboom D.W., Effect of high zinc diets on TGE-challenged early weaned piglets, J. Anim. Sci. 78 (1998) 52.

[77] Stokes C.R., Bailey M., Haverson K., Harris C., Jones P., Inman C., Pié S., Oswald I.P., Williams B.A., Akkermans A.D.L., Sowa E., Rothkoetter H.J., Miller B.G., Postnatal development of intestinal immune system in piglets: implications fore the process of weaning, Anim. Res. 53 (2004) 325-334.

[78] Strobel S., Mowat A.M., Immune responses to dietary antigens: oral tolerance, Immunol. Today 19 (1998) 174-181.

[79] Teitelbaum J.E., Walker W.A., Nutritional impact of pre- and probiotics as protective gastrointestinal organisms, Annu. Rev. Nutr. 22 (2002) 107-138.

[80] Tsiloyiannis V.K., Kyriakis S.C., Vlemmas J., Sarris K., The effect of organic acids on the control of porcine post-weaning diarrhoea, Res. Vet. Sci. 70 (2001) 287-293.

[81] Tsukahara T., Ushida K., Succinate accumulation in pig large intestine during antibioticassociated diarrhea and the constitution of succinate-producing flora, J. Gen. Appl. Microbiol. 48 (2002) 143-154.
[82] Underdahl N.R., The effect of feeding Streptococcus faecium upon Escherichia coli induced diarrhea in gnotobiotic pigs, Prog. Food Nutr. Sci. 7 (1983) 5-12.

[83] Ushe T.C., Nagy B., Inhibition of small intestinal colonization of enterotoxigenic Escherichia coli by Streptococcus faecium M74 in pigs, Zentralbl. Bakteriol. Mikrobiol. Hyg. [B] 181 (1985) 374-382.

[84] Uzzau S., Fasano A., Cross-talk between enteric pathogens and the intestine, Cell. Microbiol. 2 (2000) 83-89.

[85] Vallee B.L., Falchuk K.H., The biochemical basis of zinc physiology, Physiol. Rev. 73 (1993) 79-118.

[86] van Heugten E., Spears J.W., Kegley E.B., Ward J.D., Qureshi M.A., Effects of organic forms of zinc on growth performance, tissue zinc distribution, and immune response of weanling pigs, J. Anim. Sci. 81 (2003) 20632067.

[87] Van Immerseel F, De Buck J., Pasmans F. Velge P., Bottreau E., Fievez V., Haesebrouck F., Ducatelle R., Invasion of Salmonella enteritidis in avian intestinal epithelial cells in vitro is influenced by short-chain fatty acids, Int. J. Food Microbiol. 85 (2003) 237248.

[88] Walsh S.V., Hopkins A.M., Nusrat A., Modulation of tight junction structure and function by cytokines, Adv. Drug Deliv. Rev. 41 (2000) 303-313.

[89] Wapnir R.A., Zinc deficiency, malnutrition and the gastrointestinal tract, J. Nutr. 130 (2000) 1388S-1392S.

[90] Xavier R.J., Podolsky D.K., How to get alongfriendly microbes in a hostile world, Science 289 (2000) 1483-1484.

[91] Zhang G., Ross C.R., Blecha F., Porcine antimicrobial peptides: new prospects for ancient molecules of host defense, Vet. Res. 31 (2000) 277-296. 